\title{
A Woman Leading to God: The Mystery of Divine and Human Joy - Shown and Explained by Julian of Norwich
}

\author{
Marcin Godawa \\ The Pontifical University of John Paul II in Krakow, Poland
}

\begin{abstract}
Among many roles played by women in human history the person who experiences God's mysteries and wants the others to follow her way seems to be a topic of great spiritual, humanistic and scientific importance. Considering this specific path allows researchers to think coherently about woman by taking an account of religious dimensions of life and by stressing the fact that faithfulness to the Church teaching does not interfere with one's individual life. For some historical reasons but mainly for an expressive message the spirituality of Julian of Norwich, an English lay woman and a mystic living in the breakthrough of XIV and XV centuries is worth examination, especially as she joins the stream of inner feelings with the theological background both showing and explaining her profound life. This analysis of her Revelations of Divine Love contains the issue of human and divine joy divided into three points: namely 1/ the coexistence of suffering and joy in Christ 2/ the delightful character of His Passion and 3/ the mutual relationship between God and man. This spiritual prospect seen as a historical event appears also as a point of reference to contemporary human mind.
\end{abstract}

Keywords: Christ, the Holy Trinity, suffering, joy, mutual relationship between God and man. 
In the world of the Bible the figure of a woman leading to God appears evidently. While such people like Debora or Judith showed the Old-Testament strong will to fulfill God's plan, their followers like Mary or Mary Magdalene revealed an incomparable share in Jesus' mission. In their life, personal courage was, and is linked to an experience of exploring divine mysteries with love. This ideal remained vivid during later ages to mention exemplary the ancient-Christian female martyrs like St. Agnes or the broad and intensive movement of nuns and virgins and emerged with a new freshness in the medieval mysticism of the XIIIXV centuries with the great names of St. Clara of Assisi, St. Catherine of Siena, St. Brigitte and many others ${ }^{1}$. This phenomenon could be better perceived if the spiritual climate of that epoch is taken into account. From the XII century along with its symbols - St. Bernard of Clairvaux or St. Anselm - a place for femininity in theology became wider and wider. The devotion of that time included such 'female' elements like the functions of feelings or bodily life in prayers and even in theological explanations ${ }^{2}$. Bernard's motive of motherly nourishing could be acknowledged as an epitome of that process which resulted in significant theological ideas like understanding the similarity of man to God based also on the female aspects of humanity or in perceiving Christ as a Mother. The vivid development of spirituality along with its specific, usually vernacular languages supplemented the achievements of the official, Latin theology. Thus, the area of human inner life had been wholly respected to become more consciously a place of sanctification.

In this stream Julian of Norwich, who lived in the breakthrough of XIV and $\mathrm{XV}$ centuries, is singled out as an intriguing object of research for a few reasons. Living as an anchoress, though probably a Benedictine nun ${ }^{3}$, she has indicated the possibilities for genuine intense spiritual life to be experienced beyond the everyday contact with the religious order and, for this reason, closer to lay people. Being a woman she represented flourishing mysticism but in contrast to her time she revealed herself not only as a mystic but also as an expert theologian ${ }^{4}$

1 The present examination concerns the religious field but the role of a woman as a leader is much wider and really interesting. E. Gilson describes Laura's spiritual influence on Dante as well as a number of different relations between famous couples [cf. E. Gilson, Szkoła muz, trans. B. Majchszak, Instytut Wydawniczy PAX, Warszawa 1965].

2 Cf. T. Merton, O Świętym Bernardzie, trans. E. Dąbrowska, Tyniec Wydawnictwo Benedyktynów, Kraków 2005, p. 72, 178-193.

3 Cf. R. Llewelyn, All Shall Be Well. The Spirituality of Julian of Norwich for Today, Paulist Press, New York/Mahwah 1982, p. 6.

4 Julian's work reveals its link to pseudo-Dionysius theology as well as its closeness to the environment of The Cloud of Unknowing [cf. R. Llewelyn, All Shall Be Well..., op. cit., p. 81-93]. Julian was supposed to get Benedictine education [cf. R. Llewelyn, All Shall Be Well..., op. cit., p. 6]. Her auto-declaration as 'a simple, unlettered creature' is con- 
who can explain her own vision ${ }^{5}$ and who is nowadays well-known for the ideas like the universal salvation connected with God's mysterious final deeds and marked by the famous sentence: 'All shall be well' or Jesus' motherhood ${ }^{6}$ as a part of the Trinity's relation to the world. Her spiritual and theological message also strikes with the vision of human joy transformed by its union with divine grace. The profound spiritual delight, which crosses the ordinary borders of feelings, occurred within her spiritual life but intentionally was to be shared by others ${ }^{7}$. Thereby, her own enjoyment marks out the perspective of an analogical experience open to everybody and, although containing differences owing to individual conditions, it is after all based on the common reality of Creation and Salvation and therefore still remains interpersonally communicational. As a fruit of the analysis of Julian's Revelations of Divine Love $e^{8}$ the prospect of human and divine joy will be presented here in three points, namely $1 /$ the coexistence of suffering and joy in Christ 2/ the delightful character of His Passion and 3/ the mutual relationship between God and man.

sidered by D. Nowakowski Baker to point out different interpretations but ultimately making room for accepting her possible knowledge of Latin, a vernacular language and theology. The citied words accentuate the spiritual dimension of her work rather than refer to the question of education. The author is going to show Julian's transition from a mystic to a theologian [cf. D. Nowakowski Baker, Julian of Norwich's Showings. From Vision to Book, Princeton University Press, New jersey 1997, p. 8-14]. Julian's deed could be perceived as related to such theological ideas like the concept of imago Dei, mystical Neoptatonism, exemplarism, sapiential literature, predestination, the thought of St. Augustine and St. Bernard of Clairvaux. Also her original theological contribution consisting in, for example, reconceiving the vision of man by rejecting the gender division of a soul should be underlined [cf. D. Nowakowski Baker, Julian of Norwich's Showings..., op. cit., p. 107-134].

5 Cf. T. Merton's opinion on Julian citied in: R. Llewelyn, All Shall Be Well..., op. cit., p. 6].

6 This one of the main Julian's ideas constitutes the three-folded comprehension. Firstly, the Son is a Mother in the creation of the world because He is the true image of the Father according to whom all was made [Christian exemplarism]. In this aspect $\mathrm{He}$ is a co-maker of human substance. Secondly, Jesus is a Mother in re-creation of man that is harmonizing in Himself human sensuality with the substance. Thirdly, He is a Mother who gives life to the Church [cf. D. Nowakowski Baker, Julian of Norwich's Showings..., op. cit., p. 107-134].

7 Exemplarily, Julian's theology has been taken as a source of inspiration for present-day people in regard of the spiritual growth and in connection with the XX century psychology [cf. R. Llewelyn, All Shall Be Well..., op.cit.].

8 Julian of Norwich, Revelations of Divine Love (Short Text and Long Text), trans. E. Spearing, Penguin Books, 1998. The short version of the Revelations is here marked by $S$ while the long version by $L$ with an appropriate number. See also the Polish translation: Juliana z Norwich, Objawienia Bożej Miłości, trans. A. Gomola, W Drodze, Poznań 2007. 


\section{The Coexistence of Suffering and Joy in Christ}

The topic of joy, though it dominates over Julian's vision, does not mean that Christ's suffering is beyond her attention'. Indeed, the mystery of the Passion is strikingly depicted especially by particular motives according to the form of the revelations given to her. The image of drying could be named as one of the most expressive profiles of Jesus' death: 'It was a sorrowful change to see this extreme mortification, and, as it appeared to me, the nose shriveled and dried, and the dear body was dark and black, quite transformed from his own fair living colour into parched mortification. [...] So I saw Christ's dear flesh dying, seemingly bit by bit, drying up with amazing agony. [...] the dear body was as discoloured, as dry, as withered, as deathly, as pitiful as if he had been dead a full week, yet dying continually' [L 16].

By using some means like the adjectives or the phonetic and graphic similarity between 'dying' and 'drying', which suggests that the drying of the flesh means coming to death, Julian shows the depth of the agony combined with her reaction because, for example, the impression of the temporal extension of the dying up to one week is her own part of the experience. This passage proves her emotional and spiritual involvement as well as her daring to describe what she sees, ultimately the importance of the Passion. That is why the book starts with her cordial asking for 'vivid perception of Christ's Passion' [S 1] which would be achieved through her 'bodily sickness' and being close to death. Hence, the worth of the Passion is explored not separately or theoretically but on the way of a spiritual and mystical union. Theology and experience are united together so that the cruelty of the Passion is perceived through her personal feelings. Consequently, Julian states that the greatest pain consists in gazing at Christ who is her whole life, bliss and joy just when He suffers [cf. L 17] and that this is love which increases one's suffering, like in Our Lady's life [cf. L 18]. She also claims that 'the very summit' of human perception is 'to think and to know what he is who suffered' [L 20]. Human knowledge arises from the confrontation of Christ with His deadly pain but still remembering who Christ is both in self and to man. Sensitivity, typical of women, becomes a proper instrument of obtaining spiritual science.

Against the background of this vision, joy appears more evidently connected with suffering. She finishes the list of aspects of the Passion with 'the joy and delight of the Passion' [L 23] that means that joy strictly belongs to Christ's Paschal deed. Its final consequences are freely and fully accepted by Him: 'his love for

9 To have a proper image of Julian's theology it must be remembered that her description of suffering or the evil of sin is realistic and accurate [cf. K 18]. 
our souls is so strong that he chose the pain willingly and eagerly, and suffered it meekly and was well-pleased to do so' [L 20]. Accepting the pain allows one to observe the Saviour's spiritual life with such dimensions as freedom, joy and love which justifies all of them and is a proper motive for His sacrifice: 'endless love made him suffer' [L 52, cf. S 11]. Here arises the important theological order of values, namely love expresses itself in suffering which fruits with delight, however love for its eternal character surpasses tribulations [cf. S 11].

The coexistence of pain and joy is explained in the light of the identity of the Son of God. Reporting her triple vision of Jesus' face along with an explanation of it Julian writes: 'The first is the suffering face which he showed while he was here, dying. Although this is a sight of mourning and sorrow, it is also glad and cheerful, for he is God' [L 71]. Two states are ascribed to two of Christ's natures, respectively sorrow to the human one while gladness to the divine one so they are joined together on the same face. In this way a dogma is reflected in feelings where it can be encountered by man.

Going further, Christ is said to have a soul divided into two parts in the following way: 'the higher was at one with God in peace, in full joy and bliss; the lower part, which is sensory being, suffered for the salvation of mankind' [L 55]. This ability to join both feelings in one being is constituted by the 'glorious' hypostatic union. Experiencing simultaneously two counter states, Christ is a figure of men. Two parts of His soul evokes Julian's original anthropology in which human nature has the same composition: the higher part is attached to God by its Creation ${ }^{10}$ while the lower one is subjected to suffering as a result of the original sin. In this context the role of the Incarnation presents itself as follows: 'the higher part of our nature is bound to God in its creation; and God is bound to the lower part of our nature in taking on our flesh' [L 57]. These two aspects belonging to every man are united in Christ, in whom the higher part of human nature ['essential being'] contacts the Trinity while the lower one ['a sensory soul'] is taken on in order to be associated with the higher one so as to share its joy ${ }^{11}$. It leads to the conclusion that the presentation of joy and suffering, firstly of Christ and secondly of men, is not accidental but strictly rooted in essential consistency of Catholic dogmas. Since Christ as the 'perfect man' is a representative of humans

10 The statement that the higher part of a soul, called also 'a godly will' [cf. L 37], still remains as clear as it was created is justified by the fact that Julian means the creation of humans in God's eternal thought and will [cf. L 58].

11 Here it can be stressed again that the re-unification of the higher part of a soul ['substance', 'essential being,'] with the lower part ['sensuality', 'a sensory soul, 'lower reason'] is the second aspect of Jesus' motherhood [cf. note 6] and the breaking point in Julian's anthropology [cf. D. Nowakowski Baker, Julian of Norwich's Showings..., op. cit., p. 128-131]. 
[cf. L 57] this possibility is opened for each man so that his or her misery can be outstripped by religious exaltation [cf. L 52].

\section{Delightful Character of the Passion}

The delightful character of the Passion is depicted more vividly by means of a mystical vision, particularly with the motives of Jesus' side and heart which played such an important role in medieval spirituality. In Julian's description words of joy are used systematically: 'Then, with a glad face, our Lord looked into his side, and gazed, rejoicing; and with his dear gaze he leads his creature's understanding through the same wound into his side. And then he revealed a beautiful and delightful place which was large enough for all mankind who shall be saved to rest there in peace and love' [L 24]. The movement inserted in this passage is meaningful. It starts from the Lord's 'glad face, which is the first contact point between Him and man. Next the Saviour's gaze accompanied by joy ['rejoicing'] is going out from this face to take the human mind into His holy side. It should be noticed that Jesus' gaze along with human understanding follow the way of a spear which had opened His side. This double perspective figuratively indicates the fact that due to God's plan, suffering is introduced to the joy of Salvation. Consequently, the side and heart are a beautiful and delightful place' in other words the deepest point of the Passion is a place of final joy where the history of Salvation is to be fulfilled. The grandeur of the joy is illustrated by 'spatial' measures because the place is 'large enough for all mankind. This point evokes the universalism of Salvation, in particular Julian's version where the potential question of predestination arises. Regardless of the number of saved people, Jesus's side finally reveals itself as a place of resting in peace and love for them.

The strict bond between the Lord's suffering and endless character of His joy occurs evidently on many pages of Revelations. In this stream Julian cites the words of Jesus who assures her: 'If you are pleased [of the Salvation], I am pleased. It is a joy, a delight and an endless happiness to me that I ever endured suffering for you, and if I could suffer more, I would suffer more' [L 22]. This declaration of great importance is next commented on and theologically explained. Jesus does not care about His death though it is 'cruel' and 'shameful' because His attention is turned to the joy. Suffering reveals here not only as an introduction but also as a means of an expression of joy. Another passage contains three essential aspects of the topic: 'How should I not do all that I can for love of you? - for doing so does not grieve me, since I would die for love of you so often with no concern of my bitter pain' [L 22]. It clearly shows that 
1/ love is a proper motive of Christ's action; 2/ He wants to do His best for man especially through death; 3 / all hardships do not produce any concern in Jesus. For Christ to suffer means to feel 'endless happiness' and His joy is 'complete', because if $\mathrm{He}$ 'could have ordered it any better, his joy could not have been complete' [L 22].

This question could be developed by the issue of the limits of pain. The Lord is systematically ascribed with the motive of 'suffering more'. Julian admits that His human nature could suffer only once [L 22], however, He 'would do it every day, if it were possible. The limit imposed upon Christ's humanity is sharply confronted with His will to suffer and die with no limits in order to stress His endless love, which is the principle of His deed. Julian expresses this infinite dimension by expressions combining the measure of time with the measure of possibility: 'as often as He was able to die', 'how often he would die, if he could', 'he would do it every day, if it were possible', 'if he could suffer more, he would, even if it were not necessary' [L 22]. This love is so strong that it surpasses the line of necessity and covers the whole field of possibility. If any limitation does occur then it is the limitation of creature that is of Christ's humanity or of time, in which the Passion is a single fact. But since His happiness linked with suffering is 'endless' it means that indeed Christ has no limits, and that will be shown below in the other form.

Christ's infinite, potential will to suffer should be supplemented by the image of His suffering which continues. Julian says that after His Ascension into heaven, being already 'beyond human pain', He 'is still suffering with us' [L 20]. That was previously treated as potential readiness is now displayed as actualization. In accordance with the statement that Christ suffered only once He, is thought as being 'beyond pain' so that the order of His earthly life [kenosis] has been completed. However, in heaven His will expresses itself in the free and divine acceptance of pain which does not conflict with His happiness. Here another of Julian's visions is even greater and more affective - Christ's blood after the Ascension 'bleeds and intercedes for us with the Father - and this shall be as long as there is need. And it flows throughout the heavens for ever, rejoicing in the salvation of all mankind who are there and shall be there, and making up the number that is lacking'[L 12]. The verbs show that the Blood is still in circulation captured in the theologically important triad: 'bleeds' - 'intercedes' - 'rejoices'. Bleeding in connection with 'is still suffering' proves the reality of Christ's suffering. This movement finds its justification in intercession between men and the Father; however, the Blood is seen not as a static plenty of merits, but dynamically, as to flow or to be poured.

Suffering symbolized by the Blood simultaneously is the joy associated with the salvation of mankind. Here the limit of this heavenly Passion could be 
searched. On the one hand the movement of the Blood seems to be measured ['as long as there is need'] ${ }^{12}$ while on the other hand the Blood 'flows for ever'. This double apprehension can be motivated by the fact that in vision distinctiveness and precision are dominated by a tenor image but it also could be supposed that flowing of the Blood means the suffering not being identical to that and therefore the circulation will last when the pain stops. In this prolonged sense 'the Blood flowing for ever' is the attribute of Christ living forever and ever. This explanation corresponds to the picture of Jesus sitting at his Father's right hand 'in rest and peace' [L 51] that is in the final fulfilment of the saving deed ${ }^{13}$.

At this point, one more dimension of the joy must be evoked. Although Christ's enjoyment is strictly connected with people it also remains in the Holy Trinity's life. Jesus' sitting at the Father's hand, mentioned above, signifies 'the highest rank of the Father's joy' [L 51]. Like with the Son this ultimate rejoicing is preceded by the coexistence of sorrow and joy in the Father whose sorrow was for the fall of Adam whereas the joy and bliss was for His Son. Both objects of the Father's attitude are ascribed with 'love' because Adam is 'his most loved creature' while the Son is 'his beloved Son, who is equal to the Father' [L 51] that shows again love as the principle of acting, now in the Father. The parallel between two divine persons in respect of having simultaneously sorrow and joy, stresses their closeness revealed in relation to the world. It points out that the mystery of pain and delight belongs to the Father too. Furthermore, it must be clearly said that joy expresses even the Trinity's inner life. Christ's declaration, citied above, contains this truth: 'It is a joy, a delight and an endless happiness to me' [L 23]. Julian expounds it as follows: 'a joy' means 'the pleasure of the Father', 'a delight' - 'the glory of the Son', 'an endless happiness' - 'the Holy Ghost' to state later: 'The Father is pleased, the Son is glorified, the Holy Ghost rejoices' [L 23]. Three synonyms could indicate contemporaneously a similarity and a difference that is the same divine nature shared by the three different persons. Then the active verb ['rejoices'] against two passive ones could recall the thesis that the Holy Ghost is the joy of The Father and the Son ${ }^{14}$.

The intimate life of the Trinity is harmoniously joined with its involvement in the salvation of people. Julian writes that 'the Holy Trinity took part at the

12 Such a thing must be considered in the context of Jesus' declaration that finally 'all shall be well' and of His two mysterious deeds to be made in the end of the world [cf. L 32, 36]. It could also be compared with the statement that Jesus will never cease His work 'until all his dearest children have been born and delivered' [L 63].

13 This is Julian's most famous parable of the lord and the servant [L 51].

14 Cf. Św. Augustyn, O Trójcy Świętej, trans. M. Stokowska, Wydawnictwo Znak, Kraków 1996, VI 11; cf. W. Kasper, Bóg Jezusa Chrystusa, trans. J. Tyrawa, Wydawnictwo Wrocławskiej Księgarni Archidiecezjalnej, Wrocław 1996, p. 268-269. 
Passion of Christ' ${ }^{\prime 15}$; that only the Son suffered and therefore the Trinity is 'eternally joyful' [L 23 $]^{16}$. The joy of the three Persons is referred to Jesus' earthly mission but the liaison reaches even deeper. Here mankind is in Christ being offered to the Father and this 'present' received 'gratefully' is 'kindly' given back to Jesus by the Father. The action of uniting the historical Redemption with the Trinity's inner life is 'joy to the Father, bliss to the Son and delight to the Holy Ghost' [L 55]. Just like the above three synonyms suggest one common life of three persons in which mankind is included through Christ turning out in an admirable way to be the freely received factor of the Trinity's life.

\section{Joyful Mutual Relationship between God and Man}

The strict joyful connection between God and people also interestingly appears in the field of their mutual feelings. Sharing common joy means that one subject becomes a reason for joy to another just like in the appeal directed to men to rejoice in God because He rejoices in them [cf. L 30]. This is even more evidently displayed in the following question: 'what can make us rejoice more in God than to see in him what pleases him most greatly of all his works?' [L 67]. The highest joy for man is to perceive that he/she is the highest joy for God, because mankind remains His most perfect deed [cf. L 67]. This reciprocal relation takes a form of dwelling: 'We ought to rejoice greatly that God dwells in our soul, and we ought to rejoice much more greatly that our soul dwells in God' [L 54], in which the difference between two reasons for joy is justified by the difference between creature and the Creator.

In the dynamic relationship a very important role is played by knowing. A general rule contains two dimensions: 'we ought to rejoice in him for all that he shows and all that he hides' [L 36] to find 'great pleasure' there. On the one hand man cherishes a desire to know which can be fulfilled only in God therefore receiving the Revelation by a soul is accompanied by the joy, which overcomes her capacity [cf. L 26]. On the other hand in this state an individual should embrace as much as God wants because God's will constitutes a measure of knowing. This limit imposed on human knowing is fully understood and accepted in imitation of the Saints in heaven who do not want to know more than is determined by

15 On account of their one common nature the Three Divine Persons are indivisible in what they are acting [cf. XI Synod w Toledo, Symbol wiary, in: Breviarium Fidei. Wybór wypowiedzi doktrynalnych Kościoła, Księgarnia Św. Wojciecha, Poznań 1997, p. 163].

16 Here suffering concerns Jesus' life, however, as it was shown above, a kind of sorrow is also ascribed to the Father. 
God. Man should enjoy knowledge in general not looking for unnecessary details except what is taught by the Church [cf. S 15, 16]. Such a human attitude not only brings benefits like peace on him but also pleases God alone [cf. L 30, S 15, 16]. The delight coming from this union sufficiently legitimizes resignation from extra-knowledge and helps a person to concentrate on given fruits of wisdom. When he/she rejoices in the certainty of faith and hope it again brings joy to the Creator [cf. L 65]. In Julian's spirituality a special kind of joy appears from her mystical visions [cf. L 8], which are to be shared with others and which forecast the perspective of contemplating God in heaven. This state means the end of pain and 'the fulfilment of all manner of joy and bliss' [L 72]. In order to catch its endless character the author uses the topos of always new saying that the joy 'will forever seem as new and delightful as it did when it was first felt' [S 9] or that it 'will last without end always beginning again' [L 63]. Thence, the earthly and heavenly delight consists in real full-of-love knowledge of God.

Besides its cognitive aspect the joy is also strong in its affective dimension. Julian describes that as if it was said by the Lord: 'rejoice in me for my love, for of all things that is how you can give me most pleasure' [L 36]. This leads to the conclusion that the act of enjoying Christ's love is not only a pleasure for man but also a cause for the Saviour's highest delight. On the other page she mentions 'a godly will' in human higher nature ['essential being'], which effects that human actions please Him forever [cf. L 37]. Jesus seems to be determined by human attitude and Julian dares to stay that there is 'the incompleteness' in Him until people are not yet in heaven, so that Christ 'does not have us in himself as wholly as he will have then' [S 15]. From this perspective it is clearly seen how God's free and loving acceptance offered to man makes their relationship close so that in the mutual influence they both are partners and factors of changes. However the final point of human development presupposes the transformation of will into God's will [cf. L 42] being achieved through this bilaterally conditioned action perceived as a way of joy.

Among the activities which stirs God's delight, Julian singles out prayer [cf. S 19], 'humbling oneself', accepting 'bodily sickness sent by God', a specific relation to the world [cf. L 39], self-improvement [cf. S 14], an atonement for sins [cf. L 29] and bearing sufferings 'gladly and lightly' [cf. S 24]. The latter is particularly undertaken on many pages of Revelations so as to show the power of sanctified humanity. If a soul has been formed by the Holy Ghost she is able to take 'willingly and gladly' 'the scourging and chastening' sent by God [cf. L 77] ${ }^{17}$. In this way man becomes similar to Christ in regard of connecting pain and

${ }_{17}$ For the role of impediments as instruments of spiritual development following Julian's thought see R. Llewelyn, All Shall Be Well..., op. cit., p. 27-35]. 
joy together until a final liberation [cf. L 64]. Being a partaker of this union an individual derives benefits from there [cf. S 24] and one of them is the change of his or her self-reference. Julian marks a meaningful dependence: 'the more lightly people take their hardships or the less importance they give them because of love, the less they shall suffer from them and the more they will be rewarded' [S 20]. In this way man is enabled to transcend suffering and transmute himself in the spirit of the joy coming from Christ. Concentration on self and one's own sufferings must be replaced by taking them lightly and considering them as nothing that is possible on condition that man opens his mind to know God 'for if we knew him and loved him, we should have patience and be completely at rest and everything that he does should be pleasing to us' [S 20].

\section{Conclusion}

The analysis of Julian's book presents the issue of human and divine joy starting from the coexistence of suffering and joy in Christ through the delightful character of His Passion up to the mutual relationship between God and man. This message is intentionally addressed by her to the rest of the people so that it could become a point of reference to the contemporary human mind in the form of the question why not to walk this path.

The example of the author of Revelations reminds us of a very important condition, namely the union of inner life with the authority of the Church which represents God alone. She willingly and harmoniously joined her own personal experience of Jesus with the auto-explanation of that and furthermore with her obedience to the Church. When she could not understand any truth she nevertheless placed it in the frame of the Church waiting for a future solution from God's power [cf. L 9.32]. Such an attitude allows one to achieve his or her whole spiritual experience on a safe way and to be protected from two dangerous extremes of minimalism and self-pride. Even if following Julian's courage and loving faithfulness causes trouble, it is a truly blessed trouble in the actual and still valid prospect of happiness.

\section{References}

Gilson Etienne, Szkoła muz, trans. B. Majchszak, Instytut Wydawniczy PAX, Warszawa 1965. Julian of Norwich, Revelations of Divine Love (Short Text and Long Text), trans. E. Spearing, Penguin Books, 1998. Juliana z Norwich, Objawienia Bożej Miłości, trans. A. Gomola, W Drodze, Poznań 2007. 
Kasper Walter, Bóg Jezusa Chrystusa, trans. J. Tyrawa, Wydawnictwo Wrocławskiej Księgarni Archidiecezjalnej, Wrocław 1996.

Llewelyn Robert, All Shall Be Well. The Spirituality of Julian of Norwich for Today, Paulist Press, New York/Mahwah 1982.

Merton Tomasz, O Świętym Bernardzie, trans. E. Dąbrowska, Tyniec Wydawnictwo Benedyktynów, Kraków 2005.

Nowakowski Baker Denise, Julian of Norwich's Showings. From Vision to Book, Princeton University Press, New jersey 1997.

Św. Augustyn, O Trójcy Świętej, trans. M. Stokowska, Wydawnictwo Znak, Kraków 1996.

XI Synod w Toledo, Symbol wiary, in: Breviarium Fidei. Wybór wypowiedzi doktrynalnych Kościoła, Księgarnia św. Wojciecha, Poznań 1997. 